\title{
EDITORIAL
}

\section{Dinámicas contemporáneas y gestión editorial en arquitectura, urbanismo y diseño: problemáticas y perspectivas}

\author{
Contemporary dynamics and editorial management in architecture, urbanism and \\ design: problems and perspectives
}

\author{
Pedro Arturo Martinez Osorio \\ Editor
}

Martínez, P. (2016). Editorial. Dinámicas contemporáneas y gestión editorial en arquitectura, urbanismo y diseño: problemáticas y perspectivas. Procesos urbanos Número 3, Ene-Dic. 5-9. Doi:10.21892/2422085X.263

The construction of a space for the dissemination of knowledge, as a scientific journal becomes, is an arduous and complex work that requires the continuous and disinterested contribution of a group of actors, whose remuneration lies in the fulfilled duty of their contribution to science, the evolution of its disciplinary field and the development of the territories to which, through the processes of dissemination, this knowledge reaches to arrive.

With regard to the construction of a magazine in the field of Architecture, it is possible to think that this work is doubly difficult, because it is a field of construction of knowledge in which the nature and validity of its forms of production are still under discussion. In some contexts, this effort, before being stimulated, is truncated by processes and models of measurement that, instead of facilitating and strengthening the editorial management, favor the exclusion and make it difficult to gain access to new editorial processes carried out with relevance and quality, either because of the lack of clarity in their policies or the lack of knowledge of the reality of publishing dynamics in a space of knowledge as complex as that of Architecture and disciplines related to the collective construction of City, Countryside and Territory.

As a counterpart to this biased and exclusionary panorama, there are growth
La construcción de un espacio de divulgación del conocimiento, como lo es una revista científica, es un trabajo arduo y complejo que requiere del aporte continuo y desinteresado de un conjunto de actores, cuya retribución radica en el deber cumplido de su contribución para la ciencia, la evolución de su campo disciplinar y el desarrollo de los territorios a los cuales, mediante los procesos de divulgación, ese conocimiento alcanza a llegar.

Con relación a la construcción de una revista en el campo de la Arquitectura, es posible pensar que esa labor es doblemente difícil, debido a que es un ámbito de construcción del conocimiento en el cual se discute todavía la naturaleza y validez de sus formas de producción de conocimiento. En algunos contextos, ese esfuerzo, antes de ser estimulado, se ve truncado por procesos y modelos de medición que, en lugar de facilitar y fortalecer la gestión editorial, privilegian la exclusión y dificultan el acceso a reconocimiento de nuevos procesos editoriales que se realizan con pertinencia y calidad, ya sea por la falta de claridad en sus políticas o el desconocimiento de la realidad de las dinámicas editoriales en un espacio del conocimiento tan complejo como lo es el de la Arquitectura y disciplinas afines a la construcción colectiva de Ciudad, Campo y Territorio.

Como contraparte de ese panorama sesgado y de exclusión, se encuentran procesos de crecimiento como los liderados por ARLA, Asociación de 
processes such as those led by ARLA, the Association of Latin American Journals of Architecture, which offers a scenario of shared growth and learning to help improve editorial quality, visibility and impact of publications in Architecture and related disciplines. Effort that stands out for its cooperative and participative strategy, in the configuration of a platform for the dissemination and visibility of the new knowledge generated by the Latin American magazines of Architecture.

Despite the difficulties and obstacles that can be found in the way of editorial management in Architecture, Urbanism and Design, this work is considered as something extremely important, which requires a work without rest and with a lot of commitment, to deliver a product of the highest quality each time, that really constitutes a space of reflection and reference in the discussion on the fundamental problems in which the City and Territory survive in the contemporary world.

It is a pride to deliver this third issue of the scientific publication Procesos Urbanos, attached to the Faculty of Basic Sciences, Engineering and Architecture of the Corporación Universitaria del Caribe-CECAR, Colombia. Editorial management whose mission is to contribute, in a significant way, to the knowledge and development of research in the area of Architecture and disciplines related to the collective construction of City, Field and Territory.

This third issue arrives in a historical moment of many uncertainties. A time of crisis and change, in which, despite accessing information very easily, it is often manipulated and distorted, taking advantage of the naivete of the masses in order to favor the obscure interests of some groups that are born within new movements of ultra-right, racism and religious fanaticism, among other manifestations.

The City and the Territory, scenarios in transformation, product of the multiple dynamics that the contemporaneity poses, are, based on the reflections that are proposed today, a place where the optimistic effort and the desire to find answers
Revistas Latinoamericanas de Arquitectura, la cual ofrece un escenario de crecimiento y aprendizaje compartido para contribuir a mejorar la calidad editorial, la visibilidad y el impacto de las publicaciones en la Arquitectura y disciplinas afines. Esfuerzo que se destaca por su estrategia cooperativa y participativa, en la configuración de una plataforma para la divulgación y visibilidad del nuevo conocimiento generado por las revistas latinoamericanas de Arquitectura.

A pesar de las dificultades y obstáculos que puedan encontrarse en el camino de la gestión editorial en Arquitectura, Urbanismo y Diseño, se considera esta labor como algo sumamente importante, que requiere un trabajo sin descanso y con mucho compromiso, por entregar cada vez un producto de la mayor calidad, que realmente se constituya en un espacio de reflexión y referencia en la discusión sobre los problemas de fondo en que sobreviven la Ciudad y el Territorio en la contemporaneidad.

Es un orgullo entregar este tercer número de la revista de divulgación científica Procesos Urbanos, adscrita a la Facultad de Ciencias Básicas, Ingeniería y Arquitectura de la Corporación Universitaria del Caribe-CECAR, Colombia. Gestión editorial que tiene como misión contribuir, de manera significativa, al conocimiento y desarrollo de la investigación en el área de la Arquitectura y disciplinas afines a la construcción colectiva de Ciudad, Campo y Territorio.

Este tercer número llega en un momento histórico de muchas incertidumbres. Un momento de crisis y cambios, en el cual, a pesar de acceder con gran facilidad a la información, muchas veces esta se ve manipulada y distorsionada, aprovechando la ingenuidad de las masas para favorecer los oscuros intereses de algunos grupos, que salen a la luz dentro de nuevos movimientos de ultra derecha, racismo y fanatismo religioso, entre otras manifestaciones.

La Ciudad y el Territorio, escenarios en trasformación, producto de las múltiples dinámicas que plantea la contemporaneidad, son, a partir de las reflexiones que hoy se proponen, un lugar donde el esfuerzo optimista y el deseo de encontrar respuestas y soluciones, exigen el compromiso inquebrantable de arquitectos, urbanistas, diseñadores y demás profesionales 
Martínez, P. - Dinámicas contemporáneas y gestión editorial.

and solutions, demand the unbreakable commitment of architects, urban planners, designers and other professionals involved in the social production of habitat, always with a human and ecological conscience for the sustainable development of our planet.

For this issue, we have compiled some works of great importance and pertinence, due to their high degree of actuality, as they touch, in an interesting way, with depth and scientific rigor, global and local problems related to human habitat.

The article that begins this issue, a historical approach developed by the teacher Alberto Saldarriaga Roa, called "About cities: the look of yesterday and today," describes and analyzes different approaches around what has been understood and judged as a city, from the second half of the eighteenth century to the present day. The themes and positions predominant in the most representative discourses are highlighted, based on multiple references. How does the Latin American City fit as an idea in these speeches? Complexity appears as a constant present in all eyes on the city over time, which still today constitutes a scenario that involves multiple realities.

The article by architect Hans Intveem Pérez, entitled "Resilient Coastal Edge: Post-27F Learning for the Big North" is presented below. A research product that proposes a systematization of general principles of ordering for coastal spaces in the context of the Chilean landscape. It proposes strategies that allow not only the resistance of the coastal edges against catastrophic natural events, but also their efficient reconstruction and rapid adaptation to adverse circumstances. A current aspect of great importance, due to the increasing threats that the Contemporary City supports.

In the sense of analyzing problems caused by urbanization processes, two articles are presented. One, that takes as an example the city of Medellín, Colombia, of the master in landscape design Olgalicia Palmett Plata, called «Environmental externalities caused by urbanization in the city of Medellín.» And another of the sociologist and master involucrados en la producción social del hábitat, siempre con una conciencia humana y ecológica para el desarrollo sustentable de nuestro planeta.

Hemos compilado, para este número, unos trabajos de gran trascendencia y pertinencia, debido a su alto grado de actualidad, ya que tocan, de manera interesante, con profundidad y rigor científico, problemáticas de orden global y local relativas al hábitat humano.

El artículo que da inicio a este número, un abordaje histórico desarrollado por el maestro Alberto Saldarriaga Roa, denominado "Acerca de las ciudades: la mirada de ayer y de hoy", describe y analiza distintos planteamientos en torno de aquello que se ha entendido y juzgado como ciudad, desde la segunda mitad del siglo XVIII hasta la actualidad. Se resaltan, a partir de múltiples referencias, los temas y posiciones predominantes en los discursos más representativos. ¿Cómo encaja la Ciudad Latinoamericana como idea en estos discursos? Aparece la complejidad como constante presente en todas las miradas sobre la ciudad a lo largo del tiempo, la cual aún hoy constituye un escenario que envuelve múltiples realidades.

Se presenta, a continuación, el artículo del arquitecto Hans Intveem Pérez, denominado "Borde costero resiliente: aprendizaje post$27 \mathrm{~F}$ para el norte grande". Un producto de investigación que plantea una sistematización de principios generales de ordenamiento para espacios costeros en el contexto del paisaje chileno. Propone estrategias que permiten no solo la resistencia de los bordes costeros contra los eventos naturales catastróficos, sino su eficiente reconstrucción y rápida adaptación a circunstancias adversas. Aspecto de gran importancia y actualidad, debido a las crecientes amenazas que soporta la Ciudad Contemporánea.

En el sentido de analizar problemáticas producto de procesos de urbanización, se presentan dos artículos. Uno, que toma como ejemplo la ciudad de Medellín, Colombia, de la magíster en diseño del paisaje Olgalicia Palmett Plata, denominado "Externalidades ambientales ocasionadas por la urbanización en la ciudad de Medellín". Y otro del sociólogo y magíster en planificación urbana y regional Alejandro Mendoza Jaramillo, denominado "Procesos 


\section{Procesos Urbanos N³ Enero - Diciembre; 2016}

in urban and regional planning Alejandro Mendoza Jaramillo, called «Processes and logics of closed urbanizations in metropolitan areas: Bogota and Buenos Aires.» Both articles are very topical, given the nature of the problems they develop.

Two articles that deal with the theme of the fractal are then presented, A topic of great relevance taking into account the dynamics at urban and architectural level in the contemporary city. One of the architect Joely Sulbarán Sandoval, denominated «The Fractal as an Architectural Paradigm: Deconstruction versus Language of Living Standards», which makes a conceptual approach to the fractal and its relations with Architecture. The other, by the architect Alejandro Guerrero Torrenegra, called «Spontaneous Peripheries of Ciudad Bolívar, Bogotá: seen from the fractal perspective. Methodological approach», which puts the fractal in the context of the Latin American peripheries.

Next, a block of articles that reflects on specific problems of the city and the production of Architectures, with great critical sense, is constituted, in the first instance, by the work done by the architects Oscar Guevara and Diana Sevilla, denominated «Environmental urban analysis of the coastal area of the municipality of Coveñas in the department of Sucre, Colombia», in which they describe the environmental problems of the coastal border of one of the municipalities of the Colombian Caribbean, emphasizing solutions from territorial planning. Likewise, in the article of the engineer Milton Guerrero, denominated «Reservoirs of retention and green channels: tools for the control of floods and the urban planning. Case study: Turbaco municipality, Bolivar «, specific urban problems are analyzed; in order to provide solutions to identified environmental problems.

Also, the article by the architect Raimundo Portillo, «Design criteria for educational buildings in the state of Zulia», reviews the theme of the regulations applied to school architecture, analyzes and enumerates general design criteria for public educational buildings in the state Zulia, with the purpose y lógicas de las urbanizaciones cerradas en áreas metropolitanas: Bogotá y Buenos Aires". Ambos artículos de gran actualidad, dada la naturaleza de las problemáticas que desarrollan.

Se presentan, luego, dos artículos que abordan la temática del fractal. Un tópico de gran pertinencia teniendo en cuenta las dinámicas a nivel urbano y arquitectónico en la ciudad contemporánea. Uno de la arquitecta Joely Sulbarán Sandoval, denominado "El Fractal como Paradigma Arquitectónico: Deconstrucción vs. Lenguaje de Patrones Vivientes", el cual hace una aproximación conceptual al fractal y sus relaciones con la Arquitectura. El otro, del arquitecto Alejandro Guerrero Torrenegra, denominado "Periferias espontáneas de Ciudad Bolívar, Bogotá: vista desde la perspectiva fractal. Abordaje metodológico", quien pone el fractal en el contexto de las periferias latinoamericanas.

A seguir, un bloque de artículos que reflexiona sobre problemáticas específicas de la ciudad y la producción de Arquitecturas, con gran sentido crítico, es constituido, en primera instancia, por el trabajo realizado por los arquitectos Oscar Guevara y Diana Sevilla, denominado "Análisis urbano ambiental del espacio litoral del municipio de Coveñas en el departamento de Sucre, Colombia", en el cual describen las problemáticas ambientales del borde costero de uno de los municipios del Caribe colombiano, enfatizando en soluciones desde la planificación territorial. También, en el artículo del ingeniero Milton Guerrero, denominado "Embalses de retención y canales verdes: herramientas para el control de inundaciones y la planificación urbana. Caso de estudio: municipio de Turbaco, Bolívar", se analizan problemáticas urbanas específicas, con el fin de aportar soluciones a los problemas ambientales identificados.

Por su parte, el artículo del arquitecto Raimundo Portillo, "Criterios de diseño para las edificaciones educativas del estado Zulia", revisa el tema de la normatividad aplicada a la arquitectura escolar, analiza y enumera criterios generales de diseño para las edificaciones educativas públicas del estado Zulia, con la finalidad de motivar la reflexión sobre la escueta normativa nacional existente, como una contribución al mejoramiento de la calidad de la arquitectura escolar en Venezuela.
8

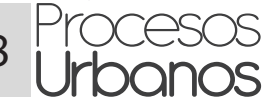


of motivating the reflection on the existing national normative, as a contribution to the improvement of the quality of the school architecture in Venezuela.

In the continuity of this block of articles, the work on visual contamination, developed by the architects Angélica Sierra Franco and Oscar Guevara, called «Visual pollution in historical centers: an aesthetic problem and of social value of the present cities», in which the authors look at this increasingly urgent problem of contemporary cities in one of the cities of the Colombian Caribbean, concerned with analyzing problems affecting the aesthetics of the urban landscape of the city and, consequently, urban competitiveness at the regional and national levels.

Finally, two articles deal with methodological aspects related to the production processes of Architecture and Design. The first, by the designer Bruna Ramírez Brito and the architect Otoniel López Altamirano, called «Transdisciplinary aspects of design and architecture: a methodological approach based on innovation», who focus on transdisciplinary methodological processes as tools that allow the designer and architect take on new concepts and techniques that contribute to innovation. And an article of my authorship entitled «The subjectivity of methodology in the design of architecture», in which I make a reflection on methodological processes used in the design of Architecture, based on a testing experience, in order to review and verify possible ways in which to approach a problem of architectural design, from the perspective of the investigation.

We are convinced that this effort to bring together such an outstanding group of works and researchers of such high quality will be to your full satisfaction. They are expected to become referents on the discussions they propose, and to stimulate reflections both in their respective places of origin and in the different contexts in which we can multiply this knowledge with the growing visibility of our journal.
En la continuidad de este bloque de artículos, el trabajo sobre contaminación visual, desarrollado por los arquitectos Angélica Sierra Franco y Oscar Guevara, denominado "Contaminación visual en centros históricos: un problema estético y de valor social de las ciudades actuales", en el cual se realiza una mirada a esta problemática cada vez más urgente de las ciudades contemporáneas, en una de las ciudades del Caribe colombiano, preocupados por analizar problemas que afectan la valoración de la estética del paisaje urbano de la ciudad y, por consiguiente, la competitividad urbana a nivel regional y nacional.

Para finalizar, dos artículos en los cuales se abordan aspectos metodológicos relativos a los procesos de producción de la Arquitectura y el Diseño. El primero, por la designer Bruna Ramírez Brito y el arquitecto Otoniel López Altamirano, denominado "Aspectos transdisciplinares de diseño y arquitectura: Un enfoque metodológico basado en la innovación", quienes se centran en procesos metodológicos transdisciplinarios, como herramientas que permiten al diseñador y arquitecto apoderarse de nuevos conceptos y técnicas que contribuyen a la innovación. Y un artículo de mi autoría denominado "La subjetividad de la metodología en la proyectación de la arquitectura", en el cual realizo una reflexión sobre procesos metodológicos utilizados en la proyectación de la Arquitectura, a partir de una experiencia de contrastación, con el fin de revisar y verificar posibles formas con las cuales abordar un problema de diseño arquitectónico, desde la perspectiva de la investigación.

Estamos convencidos de que este esfuerzo por congregar tan destacado grupo de trabajos e investigadores de tan alta calidad, será de su entero agrado. Se espera que se conviertan en referentes sobre las discusiones que proponen, y dinamicen reflexiones tanto en sus respectivos lugares de origen, como en los diferentes contextos en los cuales logremos multiplicar este conocimiento con la creciente visibilidad de nuestra revista. 